\title{
PENGARUH DEBT TO EQUITY RATIO, CURRENT RATIO, RETURN ON ASSET, TOTAL ASSET TURNOVER, DAN PERUBAHAN ARUS KAS OPERASI TERHADAP RETURN SAHAM
}

\author{
Juanita Putri Aison \\ Universitas Multimedia Nusantara \\ Rosita Suryaningsih \\ Universitas Multimedia Nusantara \\ rosita@umn.ac.id
}

\begin{abstract}
The objective of this research is to examine the effect of Debt to Equity Ratio (DER), Current Ratio (CR), Return On Asset (ROA), Total Asset Turnover (TAT), and Cash Flow from Operating (CFO) both partially and simultaneously towards share return.

The objects of this study are manufacturin companies which were listed in Bursa Efek Indonesia in the period 2010-2012. The samples are 18 companies based on purposive sampling. The data used in this study are secondary data such as share prices and financial statements.

The results of this study are (1) Debt to Equity Ratio (DER) partially has significant effect towards share return (2) Current Ratio (CR) partially has no significant effect towards share return (3) Return On Asset (ROA) partially has significant effect towards share return (4) Total Asset Turnover (TAT) partially has no significant effect towards share return (5) Cash Flow from Operating (CFO) partially has no significant effect towards share return (6) Debt to Equity Ratio (DER), Current Ratio (CR), Return On Asset (ROA), Total Asset Turnover (TAT), and Cash Flow from Operating (CFO) simultaneously have a significant effect towards share return.
\end{abstract}

Keywords: Debt to Equity Ratio (DER), Current Ratio (CR), Return On Asset (ROA), Total Asset Turnover (TAT), Cash Flow from Operating (CFO), share return

\section{Pendahuluan}

Dalam era globalisasi ini, persaingan antar perusahaan sangat ketat. Hal ini dapat dilihat dari meningkatnya jumlah perusahaan yang terdaftar di Bursa Efek Indonesia.Untuk mengembangkan usahanya dan unggul dalam persaingan, perusahaan membutuhkan dana untuk mendorong kinerja operasional perusahaan. Sumber dana perusahaan dapat berasal dari internal maupun eksternal perusahaan. Sumber dana internal pada umumnya berasal dari retained earnings, sedangkan sumber dana eksternal dapat diperoleh dari pinjaman kredit atau penjualan saham di pasar modal. 
Dalam pasar modal, salah satu instrumen pasar keuangan yang paling popular adalah saham. Pendapatan dari investasi saham dapat berupa dividen dan capital gain. .Bagi investor yang berorientasi pada investasi jangka panjang, dividen menjadi hal utama yang dipertimbangkan. Ketika perusahaan aktif memberikan dividen, maka para investor akan tertarik untuk membeli sahamnya. Sebaliknya, investor yang berorientasi pada investasi jangka pendek akan melihat capital gain yang akan diperolehnya.

Investor lebih baik melakukan analisis sebelum melakukan investasi. Investor dapat melakukan analisis terhadap pergerakan perusahaan dengan cara melakukan analisis fundamental.Menurut Munawir (1979) dalam Meythi et al. (2011), laporan keuangan merupakan alat yang sangat penting untuk memperoleh informasi sehubungan dengan posisi keuangan dan hasil yang telah dicapai oleh perusahaan yang bersangkutan.

Rasio keuangan dikelompokkan menjadi 4 jenis yaitu rasio coverage, rasio likuiditas, rasio profitabilitas, dan rasio aktivitas. Rasio coverage mengukur tingkat keamanan untuk kreditur dan investor jangka panjang. Selain rasio coverage, investor juga dapat melihat rasio lainnya sebagai pertimbangan dalam pengambilan keputusan seperti, rasio likuiditas yang digunakan untuk mengevaluasi kemampuan perusahaan memenuhi kewajiban jangka pendeknya saat jatuh tempo, rasio profitabilitas untuk mengukur performa perusahaan dan keefisiensi perusahaan dalam menghasilkan laba dan rasio aktivitas untuk mengukur seberapa efisien perusahaan dalam menggunakan asetnya.

Debt to Equity Ratio (DER) mengukur kemampuan kinerja perusahaan dalam memenuhi kewajibannya dengan melihat perbandingan antara total utang dengan total ekuitasnya. Rasio ini menunjukkan struktur modal perusahaan dengan membandingkan total utang dengan total ekuitas perusahaan. Semakin tinggi nilai DER menunjukkan bahwa tingginya kontribusi dana dari luar di dalam modal perusahaan. Investor cenderung menghindari saham-saham yang memiliki nilai DER yang tinggi karena mencerminkan risiko perusahaan yang tinggi. Peningkatan utang akan mempengaruhi besar kecilnya dividen karena saat memperoleh laba, perusahaan lebih mengutamakan untuk membayar kewajibannya daripada pembagian dividen. Apabila kontribusi utang tinggi menunjukkan rendahnya kemampuan perusahaan dalam membayar dividen, sehingga perusahaan menjadi kurang menarik di mata investor dan harga saham menjadi menurun yang mengakibatkan return saham perusahaan semakin rendah. Pernyataan ini sesuai dengan penelitian Sugiarto (2011) yang menunjukkan bahwa DER perusahaan berpengaruh negatif terhadap return saham yang berarti bahwa setiap kenaikan DER maka semakin besar total utang dibandingkan dengan total modal sendiri. Namun penelitian ini bertolak belakang dengan penelitian Nugroho (2013) dan Suarjaya (2013) bahwa DER tidak ada pengaruh terhadap return saham. Selain dipengaruhi oleh DER, return saham juga dipengaruhi oleh current ratio.

Current Ratio (CR) mengukur kemampuan perusahaan untuk melunasi kewajiban jangka pendeknya dengan aset lancar yang dimilikinya. Rasio ini dapat menunjukkan tingkat keamanan investor jangka pendek dengan menunjukkan kemampuan perusahaan untuk membayar kewajibannya. Semakin tinggi CR maka kemampuan perusahaan memenuhi kewajiban jangka pendeknya semakin tinggi. Hal ini menunjukkan bahwa perusahaan memiliki kas yang cukup sehingga memungkinkan perusahaan untuk membagikan dividen yang menyebabkan permintaan akan saham meningkat dan diiringi dengan kenaikan harga 
saham. Apabila harga saham meningkat maka return saham yang akan diperoleh investor juga akan meningkat. Hal ini didukung oleh hasil penelitian Farkhan dan Ika (2012) yang menyatakan current ratio memiliki pengaruh positif terhadap return saham. Namun penelitian ini bertolak belakang dengan penelitian Nugroho (2013) bahwa current ratio tidak memiliki pengaruh terhadap return saham.

Dalam melakukan investasi, investor perlu melihat keefektifan perusahaan dalam memperoleh laba yang dapat diukur menggunakan rasio return on asset. Return On Asset (ROA) digunakan investor untuk mengukur keefektifan perusahaan dalam memperoleh keuntungan dengan memanfaatkan aset yang dimilikinya. ROA yang tinggi menunjukkan kemampuan perusahaan dalam mengolah asetnya untuk memperoleh keuntungan yang tinggi, sehingga menimbulkan kemungkinan perusahaan akan membagikan dividen kepada pemegang saham. Hal ini akan meningkatkan permintaan saham dan harga saham akan meningkat yang diikuti dengan meningkatnya return saham yang akan diterima investor. Pernyataan ini sesuai dengan hasil penelitian Nugroho (2013), Malintan (2013) dan Ardiansyah, dkk (2012) yang menunjukkan adanya hubungan positif antara ROA dan return saham yang berarti semakin tinggi ROA maka kinerja perusahaan semakin baik dan semakin efektif perusahaan dalam memanfaatkan asetnya untuk menghasilkan laba. Sedangkan penelitian Kusumo (2011) menyatakan variabel ROA tidak memiliki pengaruh terhadap return saham.

Selain ROA, investor juga dapat mengukur keefektifan perusahaan menggunakan rasio total asset turnover. Total Asset Turnover (TAT) menunjukkan tingkat efektifitas perusahaan dalam menggunakan keseluruhan asetnya untuk meningkatkan penjualannya. Rasio ini digunakan untuk mengukur perputaran semua aset perusahaan. Semakin tinggi TAT, menunjukkan semakin efisien penggunaan aset perusahaan yang dikonversi menjadi pendapatan yang menyebabkan laba yang diperoleh perusahaan semakin tinggi. Laba yang tinggi memungkinkan perusahaan untuk membagikan dividen, sehingga investor tertarik untuk melakukan investasi dan permintaan atas saham perusahaan akan meningkat yang diiringi dengan meningkatnya harga saham dan return saham. Pernyataan ini sesuai dengan hasil penelitian Kusumo (2011) yang menyatakan TAT memiliki pengaruh terhadap return saham yang berarti TAT lebih besar cenderung memiliki return saham yang lebih besar. Namun penelitian Kusumo (2011) tidak sejalan dengan hasil penelitian Nugroho (2013) yang menyatakan bahwa variabel TAT tidak berpengaruh terhadap return saham.

Faktor lain yang perlu dipertimbangkan investor dalam melakukan investasi yaitu cash flow from operating. Cash Flow from Operating (CFO) merupakan arus kas yang diperoleh dari operasi normal perusahaan seperti produksi dan penjualan barang dan jasa. Menurut PSAK No. 02, jumlah arus kas yang berasal dari aktivitas operasi merupakan indikator yang menentukan apakah dari operasinya perusahaan dapat menghasilkan arus kas yang cukup untuk melunasi pinjaman, memelihara kemampuan operasi perusahaan, membayar dividen dan melakukan investasi baru tanpa mengandalkan pada sumber pendanaan dari luar (IAI, 2012). Arus kas operasi yang positif menunjukkan bahwa perusahaan mampu mengelola keuangan perusahaannya yang memungkinkan perusahaan untuk membagikan dividen dan menimbulkan kepercayaan masyarakat untuk melakukan 
investasi. Semakin banyak permintaan atas saham perusahaan membuat harga saham perusahaan meningkat dan return saham yang akan diperoleh investor juga meningkat. Hasil penelitian Ardiansyah, dkk (2012) menunjukkan bahwa arus kas operasi berpengaruh signifikan dengan return saham. Hasil ini berbeda dengan Trisnawati (2009) yang menunjukkan bahwa arus kas operasi tidak memiliki pengaruh signifikan terhadap return saham.

\section{Rumusan Masalah}

Berdasarkan latar belakang penelitian, maka peneliti mengidentifikasikan masalah sebagai berikut:

1. Apakah Debt to Equity Ratio (DER) memiliki pengaruh terhadap return saham?

2. Apakah Current Ratio (CR) memiliki pengaruh terhadap return saham?

3. Apakah Return On Asset (ROA) memiliki pengaruh terhadap return saham?

4. Apakah Total Asset Turnover (TAT) memiliki pengaruh terhadap return saham?

5. Apakah Perubahan Arus Kas Operasi memiliki pengaruh terhadap return saham?

\subsection{Return Saham}

\section{Tinjauan Literatur dan Hipotesis}

Saham merupakan bentuk kepemilikan perusahaan dimana para pemegang saham berharap untuk mendapatkan sejumlah return yang diterima dari pembagian dividen atau keuntungan dari kenaikan harga saham (Gitman, 2012). Brigham dan Houston (1999) dalam Kusumo (2011) menyatakan saham adalah tanda kepemilikan perusahaan, kepemilikan saham biasanya disimbolkan dengan saham biasa (common stock). Weygandt et al. (2013) dalam menjelaskan tentang saham menggunakan istilah share capital. Share capital adalah kas dan aset lainnya yang dibayarkan kepada perusahaan oleh investor untuk ditukarkan dengan saham. Berdasarkan pendapat-pendapat tersebut, dapat disimpulkan bahwa saham merupakan tanda penyertaan modal atau kepemilikan seseorang atau badan usaha dalam suatu perusahaan atau perseroan terbatas yang biasanya disimbolkan dengan saham biasa.

Menurut Mulyana (2011) harga pasar saham adalah nilai saham yang terjadi akibat diperjualbelikannya saham tersebut.Pembentukan harga saham terjadi karena adanya permintaan dan penawaran atas saham tersebut (www.idx.com). Hal ini menunjukkan semakin banyak permintaan terhadap suatu saham perusahaan, maka dapat meningkatkan harga saham perusahaan tersebut.

Dalam melakukan investasi, investor mengharapkan pengembalian. Investasi merupakan suatu kegiatan penempatan dana pada satu atau lebih dari suatu aset selama periode waktu tertentu dengan harapan akan memperoleh penghasilan atau peningkatan nilai investasi (Ansor, 2009 dalam Arista, 2012). Tujuan dari investasi ini adalah keuntungan yang didapat dari adanya perubahan harga saham yang menciptakan return yang berupa capital gain (Arista, 2012).

Dalam berinvestasi pada saham, return dapat dikategorikan menjadi realized return dan expected return. Return realisasi (realized return) merupakan return yang telah terjadi. Return ekspektasi merupakan return yang belum terjadi tetapi diharapkan investor di masa 
mendatang. Return realisasi dihitung dengan cara mengurangkan harga saham pada periode saat ini dengan harga saham pada periode sebelumnya dibagi dengan harga saham pada periode sebelumnya.

Return realisasi dihitung dengan cara mengurangkan harga saham pada periode saat ini dengan harga saham pada periode sebelumnya dibagi dengan harga saham pada periode sebelumnya. Perhitungan return saham menurut Nugroho (2013):

$$
\text { Return Sabaun }=\frac{\mathrm{E}_{\mathrm{i}}-\mathrm{E}_{\mathrm{L}-1}}{\mathrm{P}_{\mathrm{t}-1}}
$$

Keterangan:

Return Saham : Tingkat pengembalian yang diharapkan investor

$P_{i}$ : Rata-rata harga saham penutupan harian pada tahun $t$

$P_{1-1}$ : Rata-rata harga saham penutupan harian pada 1 tahun sebelum tahun $t$

\subsection{Signalling Theory}

Signalling theory adalah sinyal informasi yang dibutuhkan oleh para investor untuk menentukan bahwa investor tersebut akan menanamkan sahamnya pada perusahaan yang bersangkutan atau tidak. Pada waktu informasi diumumkan dan semua pelaku pasar sudah menerima sinyal informasi tersebut, pelaku pasar terlebih dahulu menginterpretasikan dan menganalisis informasi tersebut sebagai sinyal baik (good news) atau sinyal buruk (bad news). Jika pengumuman informasi tersebut sebagai sinyal baik bagi investor, maka terjadi perubahan dalam volume perdagangan saham (Kusumo, 2011).

Signalling theory merupakan penjelasan dari asimetri informasi. Teori ini menunjukkan bagaimana asimetris ini dapat dikurangi dengan memberikan lebih banyak signal informasi kepada pihak lain (Meythi et al., 2011).Teori sinyal juga mengemukakan tentang bagaimana seharusnya sebuah perusahaan memberikan sinyal kepada pengguna laporan keuangan. Sinyal tersebut berupa informasi mengenai kondisi perusahaan kepada pemilik ataupun pihak yang berkepentingan. Sinyal yang diberikan dapat juga dilakukan melalui pengungkapan informasi akuntansi seperti laporan keuangan, laporan apa yang sudah dilakukan manajemen untuk merealisasikan keinginan pemilik, atau bahkan dapat berupa promosi serta informasi lain yang menyatakan bahwa perusahaan tersebut lebih baik daripada perusahaan lain (Susilowati, 2011).

\subsection{Rasio Keuangan}

Menurut Munawir (1979) dalam Meythi et al. (2011), laporan keuangan merupakan alat yang sangat penting untuk memperoleh informasi sehubungan dengan posisi keuangan dan hasil yang telah dicapai oleh perusahaan yang bersangkutan. 
Analisis rasio digunakan secara khusus oleh investor dan kreditor dalam keputusan investasi atau penyaluran dana (Prihadi, 2008).Rasio keuangan dikelompokkan menjadi 4 jenis (Kieso, 2011):

\section{Rasio Coverage}

Rasio coverage atau biasa disebut capital structure ratio mengukur tingkat keamanan untuk kreditur dan investor jangka panjang (Kieso, 2011). Rasio struktur modal dan solvabilitas digunakan untuk menilai kemampuan perusahaan melunasi kewajiban jangka panjang (Subramanyam, 2009).

2. Rasio Likuiditas

Menurut Weygandt et al. (2013), rasio likuiditas digunakan untuk mengukur kemampuan jangka pendek perusahaan untuk membayar obligasi jangka pendek dan untuk memenuhi kebutuhan kas jangka pendek.

3. Rasio Profitabilitas

Rasio profitabilitas adalah hasil yang diperoleh melalui usaha manajemen atas dana yang diinvestasikan pemilik perusahaan (Kusumo, 2011). Menurut Meythi et al. (2011), rasio profitabilitas menyediakan evaluasi menyeluruh atas kinerja perusahaan dan manajemennya.

4. Rasio Aktivitas

Rasio aktivitas mengukur tingkat efisiensi perusahaan dalam penggunaan sumber dayanya. Aktiva sebagai penggunaan dana seharusnya dapat dikendalikan agar dapat dimanfaatkan secara optimal (Meythi et al., 2011).

\subsection{Debt to Equity Ratio (DER)}

Rasio ini menunjukkan dan menggambarkan komposisi atau struktur modal dari perbandingan total hutang dengan total ekuitas (modal) perusahaan yang digunakan sebagai sumber pendanaan usaha (Arista, 2012). Jika sebuah perusahaan memiliki nilai DER yang tinggi maka perusahan itu akan memiliki tingkat risiko yang tinggi pula, karena hutang yang ditanggung perusahaan juga semakin tinggi (Nugroho, 2013). Hutang diperlukan oleh perusahaan untuk menambah modal perusahaan karena dengan memiliki hutang yang besar dapat digunakan untuk meningkatkan modal perusahaan sehingga perusahaan dapat mengembangkan usaha maka investor lebih tertarik untuk membeli saham perusahaan tersebut sehingga harga saham perusahaan tersebut akan naik dan return sahamnya juga akan naik (Nugroho, 2013).

DER yang tinggi menunjukkan komposisi total hutang (hutang jangka pendek dan hutang jangka panjang) semakin besar apabila dibandingkan dengan total modal sendiri, sehingga hal ini akan berdampak pada semakin besar pula beban perusahaan terhadap pihak eksternal (para kreditur). Akibatnya perusahaan yang bersangkutan menjadi kurang menarik di mata investor (Sugiarto, 2011). Tingkat Debt to Equity Ratio (DER)yang aman biasanya kurang dari 50 persen. Semakin kecil debt to equity ratio semakin baik bagi perusahaan atau semakin aman utang yang harus diantisipasi dengan modal sendiri (Fakhruddin dan Hardianto, 2001 dalam Arista, 2012).Semakin tinggi DER menunjukkan komposisi total 
utang semakin besar dibanding dengan total modal sendiri sehingga meningkatkan tingkat risiko yang diterima investor (Malintan, 2013). .Perhitungan debt to equity ratio dapat dirumuskan sebagai berikut (Subramanyam, 2009):

$$
\text { Debt to Equity Ratio }=\frac{\text { T'otal Liabilities }}{\text { Sharcholder's Equity }}
$$

Menurut hasil penelitan Arista (2012) dan Martani et al. (2009), DER memiliki pengaruh terhadap return saham. Pada penelitian di perusahaan manufaktur menunjukkan bahwa debt to equity ratio berdampak pada penurunan return saham. Hal ini disebabkan investor masih menganggap perusahaan aman apabila komposisi hutang terhadap modal sendiri pada batas wajar (Arista, 2012). Hasil ini konsisten dengan hasil penelitian Sugiarto (2011) yang menyatakan bahwa rasio DER yang tinggi menunjukkan komposisi total hutang (hutang jangka pendek dan hutang jangka panjang) semakin besar apabila dibandingkan dengan total modal sendiri, sehingga hal ini akan berdampak pada semakin besar pula beban perusahaan terhadap pihak eksternal (para kreditur). Akibatnya perusahaan yang bersangkutan menjadi kurang menarik di mata investor. Namun hasil ini bertentangan dengan hasil penelian Nugroho (2013) yang menunjukkan bahwa DER tidak memiliki pengaruh yang signifikan terhadap return saham. Nugroho (2013) menyatakan bahwa kondisi yang berbeda juga dapat diperoleh dari investor dimana DER yang tinggi justru mencerminkan bahwa perusahaan sedang dalam pertumbuhan dimana perusahaan sangat memerlukan pendanaan yang besar yang lebih cepat diperoleh melalui kontrak hutang dengan pihak ketiga. Hasil penelitian Nugroho (2013) konsisten dengan Farkhan dan Ika (2012) yang menyatakan tidak adanya pengaruh DER terhadap return saham dikarenakan sebagian investor hanya menganggap bahwa perusahaan yang memiliki prospek keberanian yang baik untuk menggunakan hutang yang tinggi dalam struktur modalnya, maka proporsi hutang yang semakin tinggi akan menyebabkan fixed payment yang tinggi dan akan menimbulkan risiko kebangkrutan atau terlikuidasi.

Hipotesis alternatif untuk hubungan DER dan return saham yang akan diuji dalam penelitian ini adalah sebagai berikut:

\section{$\mathrm{Ha}_{1}$ : Debt to Equity Ratio (DER) memiliki pengaruh terhadap return saham}

\subsection{Current Ratio (CR)}

Current ratio paling umum digunakan untuk mengukur kemampuan perusahaan dalam memenuhi kewajibannya saat jatuh tempo (Fraser, 2010). Current ratio mengukur aset lancar yang tersedia untuk melunasi kewajiban lancar (Subramanyam, 2009). Menurut Wegandt et al. (2013), current ratio is a measure used to evaluate a company's liquidity and short-term debt-paying ability; computed by dividing current assets by current liabilities. 'Rasio lancar (current ratio) adalah rasio untuk mengukur seberapa jauh aset lancar (aktiva lancar) perusahaan mampu untuk melunasi kewajiban jangka pendeknya. Semakin tinggi rasio ini 
akan semakin aman bagi kreditor (Prihadi, 2008). Perhitungan current ratio dapat dirumuskan sebagai berikut (Subramanyam, 2009):

$$
\text { Current Ratio }=\frac{\text { Current assets }}{\text { Current Liabilities }}
$$

Semakin tinggi nilai $C R$ mengindikasikan tingkat likuiditas yang tinggi pada perusahaan. Seberapa besar tingkat likuiditas yang dibutuhkan suatu perusahaan tergantung dari beberapa faktor seperti ukuran perusahaan, akses perusahaan pada sumber dana jangka pendek seperti batas kredit bank, serta volatilitas dari bisnis perusahaan (Gitman, 2012). Namun beberapa investor memiliki pendapat yang berbeda, dimana $C R$ yang tinggi justru mencerminkan kemampuan perusahaan untuk mengoptimalkan aktiva lancar dalam kondisi yang kurang baik. Karena dengan nilai $C R$ yang tinggi ini ternyata return saham yang dihasilkan perusahaan hanya kecil (Nugroho, 2013).

Hasil penelitian Farkhan dan Ika (2012) menunjukkan bahwa Current Ratio (CR) memiliki pengaruh positif terhadap return saham, yang menyatakan bahwa jika aset lancar yang dimiliki perusahaan naik, berarti perusahaan mampu dalam melunasi kewajiban jangka pendeknya yang nanti akan dapat menaikkan profitabilitas perusahaan dan juga akan berpengaruh terhadap return saham. Hasil penelitian Devi (2012) juga menunjukkan bahwa CR memiliki pengaruh yang negatif dan signifikan terhadap pendapatan saham. Hasil penelitian menunjukkan pengaruh $\mathrm{CR}$ negatif terhadap pendapatan saham dikarenakan $\mathrm{CR}$ yang tinggi dapat disebabkan karena adanya piutang yang tak tertagih dan persediaan yang belum terjual, sehingga tidak dapat digunakan secara cepat untuk membayar hutang lancarnya. Hasil penelitian Devi (2012) tidak konsisten dengan penelitian Nugroho (2013). Menurut hasil penelitian Nugroho (2013), nilai CR yang tinggi tidak mempengaruhi minat investor dalam menanamkan modalnya, karena tingginya nilai CR menunjukkan kemampuan perusahaan dalam mengelola aset lancar yang kurang baik, sehingga mengakibatkan banyak aset lancar yang mengganggurdan tidak dioptimalkan oleh perusahaan yang berakibat pada menurunnya minat investor dalam menanamkan modalnya. Minat investor yang menurun ini berimbas pada turunnya harga saham perusahaan sehingga mengakibatkan return saham perusahaan juga ikut menurun. Hasil ini sesuai dengan penelitian Kusumo (2011) yang menyatakan CR yang tinggi seringkali mencerminkan bahwa perusahaan terlalu banyak menumpuk aset mereka pada kas, persediaan dan hutang lancar yang berarti perusahaan kurang mampu memutar aset-aset mereka.

Hipotesis alternatif untuk hubungan CRdan return saham yang akan diuji dalam penelitian ini adalah sebagai berikut:

\section{$\mathrm{Ha}_{2}$ : Current ratio (CR) memiliki pengaruh terhadap return saham}

\subsection{Return On Asset (ROA)}

Return On Asset merupakan salah satu rasio return on investment yang digunakan untuk menilai keuntungan finansial bagi pemasok modal dan pembiayaan utang (Subramanyam, 2009). Return On Asset (ROA, laba atas aset) mengukur tingkat laba terhadap aset yang 
digunakan dalam menghasilkan laba tersebut (Prihadi, 2008). Menurut Fraser (2010), return on asset mengukur efisiensi perusahaan dalam mengatur total investasi dalam aset dan memberikan return kepada para pemegang saham. Return on asset dapat dirumuskan sebagai berikut (Kieso, 2011):

$$
\text { Return On Asset }=\frac{\text { Not income }}{\text { Averago Total Assets }}
$$

Perusahaan dengan kemampuan menghasilkan laba yang tinggi lebih menarik minat investor untuk melakukan investasi di perusahaan tersebut, sehingga jika banyak investor yang tertarik untuk melakukan investasi maka harga saham perusahaan tersebut akan naik dan mengakibatkan return saham dari perusahaan tersebut juga naik (Nugroho, 2013).Hasil penelitian Nugroho (2013) konsisten dengan Farkhan dan Ika (2012). Hal ini mengidentifikasikan bahwa nilai perusahaan ditentukan oleh earning power dari aktiva perusahaan. Semakin tinggi earning power maka semakin tinggi pula tingkat efisiensi perputaran aktiva dan semakin tinggi pula profit margin yang diperoleh perusahaan, yang akan berdampak pada peningkatan nilai perusahaan dan mengakibatkan return saham meningkat (Farkhan dan Ika, 2012).

Hasil penelitian Nugroho (2013) menunjukkan bahwa ROA memiliki pengaruh positif signifikan terhadap return saham. Hal ini karena perusahaan dengan kemampuan menghasilkan laba yang tinggi lebih menarik minat investor untuk melakukan investasi di perusahaan tersebut, sehingga jika banyak investor yang tertarik untuk melakukan investasi maka harga saham perusahaan tersebut akan naik dan mengakibatkan return saham dari perusahaan tersebut juga naik.Hasil penelitian Nugroho (2013) konsisten dengan Farkhan dan Ika (2012). Hal ini mengidentifikasikan bahwa nilai perusahaan ditentukan oleh earning power dari aktiva perusahaan. Semakin tinggi earning power maka semakin tinggi pula tingkat efisiensi perputaran aktiva dan semakin tinggi pula profit margin yang diperoleh perusahaan, yang akan berdampak pada peningkatan nilai perusahaan dan mengakibatkan return saham meningkat (Farkhan dan Ika, 2012). Hasil penelitian Devi (2012) juga menunjukkan bahwa secara parsial ROA berpengaruh positif terhadap pendapatan saham. Hasil penelitian Devi (2012) menyatakan bahwa ROA tidak semata-mata dijadikan ukuran dalam menilai kinerja perusahaan oleh investor dalam memprediksi return saham di pasar modal. Hasil penelitian Nugroho (2013) konsisten dengan hasil penelitian Malintan (2013), dan Farkhan dan Ika (2012).

Hipotesis alternatif untuk hubungan ROAdan return saham yang akan diuji dalam penelitian ini adalah sebagai berikut:

\section{Ha3: Return On Asset (ROA) memiliki pengaruh terhadap return saham}

\subsection{Total Asset Turnover (TAT)}

Menurut Gitman (2012), "total asset turnover indicates the efficiency with which the firm uses its assets to generate sales". Rasio ini mengukur seberapa optimal kemampuan perusahaan menghasilkan penjualan berdasarkan seluruh aset yang dimilikinya atau 
perputaran aset-aset tersebut (Nugroho, 2013).Total asset turnover merupakan rasio yang digunakan untuk mengukur seberapa baik tingkat efisien dalam seluruh aktiva perusahaan untuk menunjang kegiatan penjualan, yang dimana total asset turnover yang menghubungkan antara penjualan dengan total aktiva (Farkhan dan Ika, 2012). Total asset turnover dapat dirumuskan sebagai berikut (Subramanyam, 2009):

$$
\text { Total Asset Turnover }=\frac{\text { Sales }}{\text { Average Totol Asset }}
$$

Semakin tinggi TAT berarti semakin efisien penggunaan aset tersebut. Jika perusahaan dapat menggunakan asetnya secara optimal, maka penjualan perusahaan akan meningkat. Perusahaan yang mampu mengoptimalkan asetnya dan meningkatkan penjualannya akan lebih menarik untuk investor, hal ini akan meningkatkan return saham dari perusahaan tersebut dan dapat dilihat dari peningkatan harga saham perusahaan (Nugroho, 2013).

Kusumo (2011) menyatakan bahwa nilai TAT yang besar oleh perusahaan memiliki kemampuan untuk menjua produk-produk mereka dengan cepat. Dengan semakin cepatnya perputaran aset perusahaan, hal ini mengindikasikan bahwa perusahaan memiliki potensi yang besar untuk mendapatkan keuntungan dan mengalami pertumbuhan, sehingga hal ini dapat menarik minat investor. Kondisi demikian dapat mengakibatkan kenaikan harga saham.

Hasil penelitian Kusumo (2011) mendapatkan bahwa TAT memiliki pengaruh yang signifikan terhadap return saham. Kusumo (2011) menyatakan bahwa nilai TAT yang besar oleh perusahaan memiliki kemampuan untuk menjua produk-produk mereka dengan cepat. Dengan semakin cepatnya perputaran aset perusahaan, hal ini mengindikasikan bahwa perusahaan memiliki potensi yang besar untuk mendapatkan keuntungan dan mengalami pertumbuhan, sehingga hal ini dapat menarik minat investor. Kondisi demikian dapat mengakibatkan kenaikan harga saham. Hasil penelitian Kusumo (2011) konsisten dengan hasil penelitian Martani et al. (2009) yang menunjukkan TAT memiliki pengaruh terhadap return saham. TAT mencerminkan efisiensi perusahaan dalam menggunakan asetnya untuk memperoleh laba dalam kegiatan operasinya. Nilai TAT yang tinggi memberikan keuntungan untuk perusahaan dan dapat memberikan pengaruh positif terhadap return saham (Martani et al., 2009). Hasil penelitian Farkhan dan Ika (2012) menunjukkan bahwa variabel Total Asset Turnover (TAT) memiliki pengaruh yang negatif dan tidak signifikan terhadap return saham. Karena dalam aktivitas perusahaan yang rendah pada tingkat penjualan tertentu, akan mengakibatkan semakin besarnya dana kelebihan yang tertanam pada aktiva-aktiva yang tidak produktif, sehingga dapat menyebabkan TAT menjadi turun. Kejadian lainnya juga bisa menjadi dampak pada total aset misalnya saat perekonomian kurang baik atau terjadi inflasi. Hasil penelitian ini tidak konsisten dengan hasil penelitian Nugroho (2013) bahwa TAT tidak memiliki pengaruh yang signifikan terhadap return saham. Nugroho (2013) menunjukkan bahwa kemampuan perusahaan untuk mengoptimalkan asetnya secara efektif dan efisien ternyata tidak berpengaruh terhadap minat investor untuk membeli saham perusahaan tersebut.

Hipotesis alternatif untuk hubungan TATdan return saham yang akan diuji dalam penelitian ini adalah sebagai berikut: 


\section{Ha $:$ Total Asset Turnover (TAT) memiliki pengaruh terhadap return saham}

\subsection{Cash Flow from Operating (CFO)}

Menurut Kieso (2011), laporan arus kas adalah laporan keuangan yang menyajikan penerimaan kas, pembayaran kas, dan perubahan kas yang dihasilkan dari aktivitas operasi, investasi, dan pendanaan dalam suatu periode.Definisi dari ketiga aktivitas tersebut adalah (IAI, 2012):

1) Aktivitas operasi adalah aktivitas penghasil utama pendapatan entitas dan aktivitas lain yang bukan merupakan aktivitas investasi dan aktivitas pendanaan.

2) Aktivitas investasi adalah perolehan dan pelepasan aset jangka panjang serta investasi lain yang tidak termasuk setara kas.

3) Aktivitas pendanaan aktivitas yang mengakibatkan perubahan dalam jumlah serta komposisi kontribusi modal dan pinjaman entitas.

Menurut Livnat dan Zarowina (1990) dalam Suyono (2011), arus kas operasi dapat mempengaruhi harga saham, dimana perusahaan yang mampu meningkatkan arus kas dari aktivitas operasinya akan menarik investor untuk berinvestasi pada saham perusahaan tersebut, sehingga permintaan akan saham meningkat dan berdampak pada kenaikan harga saham. Jika harga saham mengalami peningkatan, maka investor dapat memperoleh capital gain. Perhitungan arus kas operasi yang digunakan dalam penelitian Nugroho (2013):

$$
C F O=\frac{C F O_{1}-C F O_{i-1}}{C F O_{i-1}}
$$

Menurut Susilowati (2010), ketika nilai arus kas operasi bernilai positif yang berarti arus kas operasi masuk lebih besar dari arus kas operasi keluar, maka hal ini memperlihatkan lancarnya kinerja perusahaan, dan hal ini akan lebih meyakinkan investor untuk melakukan investasi karena dengan lancarnya kinerja perusahaan, maka suatu hal yang mungkin bila return yang didapat investor akan lancar pula. Hasil penelitian Ardiansyah, dkk (2012) menunjukkan arus kas operasi memberikan pengaruh positif terhadap return saham secara signifikan.Hasil penelitian Susilowati (2010) menunjukkan bahwa arus kas operasi secara parsial berpengaruh signifikan terhadap return saham. Menurut Susilowati (2010), ketika nilai arus kas operasi bernilai positif yang berarti arus kas operasi masuk lebih besar dari arus kas operasi keluar, maka hal ini memperlihatkan lancarnya kinerja perusahaan, dan hal ini akan lebih meyakinkan investor untuk melakukan investasi karena dengan lancarnya kinerja perusahaan, maka suatu hal yang mungkin bila return yang didapat investor akan lancar pula. Hasil ini konsisten dengan hasil penelitian Agustina (2009), dan Sinaga (2009) yang menyatakan bahwa arus kas operasi berpengaruh terhadap return saham. Namun, hasil ini tidak konsisten dengan hasil penelitian Trisnawati (2009) yang menunjukkan bahwa arus kas operasi tidak memiliki pengaruh signifikan terhadapreturn saham.

Hipotesis alternatif untuk hubungan CFOdan return saham yang akan diuji dalam penelitian ini adalah sebagai berikut: 


\section{Has:Cash Flow from Operating (CFO) memiliki pengaruh terhadap return saham}

\section{III.Metode Penelitian}

Penelitian ini merupakan jenis penelitian uji pengaruh (causal study). Menurut Sekaran dan Bougie (2010), causal study merupakan penelitian di mana penelitinya ingin menjelaskan penyebab dari satu atau lebih masalah. Dalam penelitian ini, masalah yang diteliti yaitu return saham yang diprediksi dipengaruhi oleh DER, CR, ROA, TAT dan CFO.

Data yang digunakan dalam penelitian ini merupakan data sekunder.Data sekunder dalam penelitian ini adalah data harga saham dan laporan keuangan perusahaan manufaktur yang terdaftar di Bursa Efek Indonesia periode 2010-2012.Laporan keuangan yang digunakan merupakan laporan keuangan yang telah diaudit oleh auditor independen.Laporan keuangan diperoleh dengan cara mengakses situs Bursa Efek Indonesia (www.idx.co.id). Sedangkan data harga saham diperoleh dari www.finance.yahoo.com.

Pemilihan sampel dalam penelitian ini menggunakan metode purposive sampling. Kriteria-kriteria sampel yang digunakan dalam penelitian ini adalah sebagai berikut:

\begin{tabular}{|c|l|c|}
\hline No. & \multicolumn{1}{|c|}{ Kriteria Sampel Jumlah Perusahaan } \\
\hline 1. & Perusahaan manufaktur yang tergolong dalam & 37 perusahaan \\
& BEktor aneka industri yang berturut-turut terdaftar di & \\
\hline 2. & Telah menerbitkan laporan keuangan per tanggal 31 & 36 perusahaan \\
& $\begin{array}{l}\text { Desember yang telah diaudit oleh auditor } \\
\text { independen }\end{array}$ & \\
\hline 3. & Menggunakan mata uang Rupiah dalam laporan & 27 perusahaan \\
& keuangannya secara berturut-turut selama periode & \\
\hline 4. & Memperoleh laba setelah pajak yang positif & 18 perusahaan \\
\hline & Jumlah perusahaan yang digunakan sebagai & $\mathbf{1 8}$ perusahaan \\
& sampel dalam penelitian ini & \\
\hline
\end{tabular}

Variabel dependen dalam penelitian ini adalah return saham. Skala pengukuran variabel dependen ini menggunakan skala rasio. Jenis return yang digunakan dalam penelitian ini adalah realized return yang berupa capital gain. Return saham dihitung dengan rumus (Nugroho, 2013): 


$$
\text { Return Saham }=\frac{\mathrm{P}_{t}-\mathrm{P}_{t-1}}{\mathrm{P}_{t-1}}
$$

Variabel independen adalah variabel yang mempengaruhi variabel dependen secara positif atau negatif, artinya jika terjadi kenaikan pada variabel independen maka akan terjadi kenaikan atau penurunan pada variabel dependen. Semua variabel independen dalam penelitian ini diukur menggunakan skala rasio.Variabel independen yang diteliti dalam penelitian ini adalah:

a) Debt to Equity Ratio (DER)

Debt to equity ratio menunjukkan komposisi struktur modal dari perbandingan total utang dengan total ekuitas (modal) perusahaan. DER dhitung dengan rumus (Subramanyam, 2009):

$$
D E R=\frac{\text { Total Liabilities }}{\text { Shareholder's Equity }}
$$

b) Current Ratio (CR)

Current ratio digunakan untuk mengukur kemampuan perusahaan melunasi kewajiban jangka pendeknya dengan aset lancar yang dimilikinya.Rumus current ratio yang digunakan dalam penelitian ini adalah sebagai berikut (Subramanyam, 2009):

$$
C R=\frac{\text { Current assets }}{\text { Current Liabilities }}
$$

c) Return On Asset (ROA)

Return on asset menunjukkan kemampuan perusahaan menghasilkan laba dengan menggunakan aset yang dimilikinya.ROA dihitung dengan rumus (Kieso, 2011):

$$
\text { ROA }=\frac{\text { Net income }}{\text { Average total assets }}
$$

Rata-rata total aset dapat dihitung dengan rumus (Subramanyam, 2009):

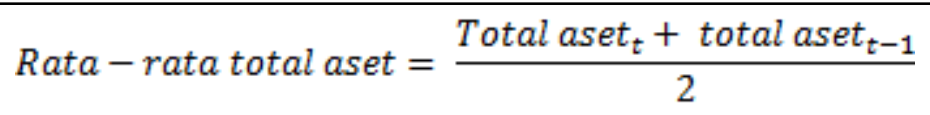


d) Total Asset Turnover (TAT)

Total Asset Turnover (TAT) digunakan untuk mengukur efisiensi perusahaan dalam menggunakan asetnya untuk menghasilkan penjualan.TAT dapat dirumuskan sebagai berikut (Subramanyam, 2009):

$$
T A T=\frac{\text { Sales }}{\text { Average Total Asset }}
$$

e) Cash Flow from Operating (CFO)

Jumlah arus kas yang berasal dari aktivitas operasi merupakan indikator yang menentukan kemampuan aktivitas operasi perusahaan dalam menghasilkan arus kas yang cukup untuk membiayai operasional perusahaan tanpa mengandalkan sumber pendanaan dari luar. Penelitian ini melihat perubahan arus kas operasi perusahaan pada periode saat ini dengan arus kas pada periode sebelumnya dibagi dengan arus kas operasi pada periode sebelumnya. CFO dihitung dengan rumus (Ardiansyah, 2012):

$$
C F O=\frac{C F O_{t}-C F O_{t-1}}{C F O_{t-1}}
$$

Pengujian hipotesis dalam penelitian ini menggunakan uji regresi linier berganda karena terdapat lebih dari satu variabel bebas (independen). Rumus regresi linier berganda yang digunakan dalam penelitian ini yaitu:

\begin{tabular}{|c|c|}
\hline Keterangan: & $=$ konstanta \\
\hline$\beta_{1}$ & $=$ koefisien variabel independen $D E R$ \\
\hline$\beta_{2}$ & $=$ koefisien variabel independen $C R$ \\
\hline$\beta_{3}$ & $=$ koefisien variabel independen $R O A$ \\
\hline$\beta_{4}$ & $=$ koefisien variabel independen $T A T$ \\
\hline$\beta_{5}$ & $=$ koefisien variabel independen $C F O$ \\
\hline$D E R$ & $=$ Debt to Equity Ratio \\
\hline$C R$ & $=$ Current Ratio \\
\hline$R O A$ & $=$ Return On Asset \\
\hline$T A T$ & $=$ Total Asset Turnover \\
\hline $\mathrm{CFO}$ & $=$ Cash flow from operating \\
\hline $\mathrm{e}$ & $=$ Standard error \\
\hline
\end{tabular}

Return Saham $=\alpha+\beta_{1} D E R+\beta_{2} C R+\beta_{3} R O A+\beta_{4} T A T+\beta_{5} C F O+\mathrm{e}$

\section{IV.Hasil dan Pembahasan}




\subsection{Statistik Deskriptif}

Perusahaan yang memenuhi kriteria pengambilan sampel dalam penelitian ini adalah 18 perusahaan. Berdasarkan jumlah perusahaan dan lama periode, banyaknya observasi dalam penelitian ini adalah 54.

Berikut ini merupakan hasil statistik deskriptif:

Tabel 4.1 Hasil Statistik Deskriptif

Descriptive Statistics

\begin{tabular}{|l|r|r|r|r|r|}
\hline & $\mathrm{N}$ & $\begin{array}{c}\text { Minimu } \\
\mathrm{m}\end{array}$ & $\begin{array}{c}\text { Maximu } \\
\mathrm{m}\end{array}$ & Mean & \multicolumn{1}{c|}{$\begin{array}{c}\text { Std. } \\
\text { Deviation }\end{array}$} \\
\hline DER & 54 & -1.5330 & 4.2951 & 1.034394 & 1.0378552 \\
$\mathrm{CR}$ & 54 & .5249 & 3.0708 & 1.554278 & .6293339 \\
ROA & 54 & .0003 & .2395 & .077537 & .0585232 \\
TAT & 54 & .2584 & 3.5294 & 1.314280 & .6266071 \\
CFO & 54 & -5.4759 & 446.7774 & 9.155594 & 60.8448647 \\
Return Saham & 54 & -.3028 & 3.2083 & .599820 & .8412586 \\
Valid N & 54 & & & & \\
(listwise) & & & & & \\
\hline
\end{tabular}

Berdasarkan hasil statistik deskriptif yang terdapat pada Tabel 4.2, jumlah sampel penelitian masing-masing variabel sebanyak 54. Nilai minimum dari Debt to Equity Ratio (DER) adalah -1.53330 dan nilai maksimumnya sebesar 4.2951. Nilai rata-rata (Mean) dari DER adalah 1.034394 dan nilai standar deviasinya adalah sebesar 1.0378552. Variabel Current Ratio (CR) memiliki nilai minimum sebesar 0.5249 dan nilai maksimum sebesar 3.0708. Nilai rata-rata (Mean) dari CR adalah 1.554278 dan nilai standar deviasinya adalah sebesar 0.6293339. Variabel Return On Asset (ROA) memiliki nilai minimum sebesar 0.0003 dan nilai maksimum sebesar 0.2395. Nilai rata-rata (Mean) dari ROA adalah 0.077535 dan nilai standar deviasinya adalah sebesar 0.0585232 .

Variabel Total Asset Turnover (TAT) memiliki nilai minimum sebesar 0.2584 dan nilai maksimum sebesar 3.5294. Nilai rata-rata (Mean) dari TAT adalah 1.314280 dan nilai standar deviasinya adalah sebesar 0.6266071. Variabel Cash Flow from Operating (CFO) memiliki nilai minimum sebesar -5.4759 dan nilai maksimum sebesar 446.7774. Nilai ratarata (Mean) dari CFO adalah 9.155594 dan nilai standar deviasinya adalah sebesar 60.8448647. Variabel return saham memiliki nilai minimum sebesar -0.3028 dan nilai maksimum sebesar 3.2083. Nilai rata-rata (Mean) dari CFO adalah 0.599820 dan nilai standar deviasinya adalah sebesar 0.8412586 .

\subsection{Uji Normalitas}

Uji normalitas dilakukan untuk menguji apakah dalam sebuah model regresi, variabel dependen/terikat, independen atau keduanya mempunyai distribusi normal (Ghozali, 2012). Model regresi yang baik memiliki distribusi data normal atau mendekati normal. Uji normalitas dilakukan dengan menggunakan Kolmogorov-Smirnov Test, dengan ketentuan apabila nilai signifikansi lebih besar dari 0,05 berarti data terdistribusi normal. Hasil pengujian menunjukkan nilai signifikansi sebesar 0.358 yang lebih besar dari 0.05 , maka data terdistribusi secara normal.

Tabel 4.2 Hasil Uji Kolmogorov-Smirnov 
One-Sample Kolmogorov-Smirnov Test

\begin{tabular}{|ll|r|}
\hline & & $\begin{array}{r}\text { Unstandardiz } \\
\text { ed Residual }\end{array}$ \\
\hline $\mathrm{N}$ & Mean & 54 \\
Normal Parameters & OE-7 \\
& Std. & .67441054 \\
Most Extreme & Deviation & .126 \\
Differences & Absolute & .126 \\
Kolmogorov-Smirnov Z & Positive & -.101 \\
\multicolumn{2}{l|}{ Asymp. Sig. (2-tailed) } & .926 \\
\hline
\end{tabular}

a. Test distribution is Normal.

b. Calculated from data.

\subsection{Uji Multikolonieritas}

Uji multikolonieritas adalah untuk menguji apakah dalam model regresi ditemukan adanya korelasi antar variabel bebas (independen). Model regresi yang baik seharusnya tidak terjadi korelasi di antara variabel independen. Untuk mendeteksi ada atau tidaknya multikolinieritas di dalam model regresi, salah satu caranya dapat dilihat dari nilai tolerance dan lawannya yaitu Variance Inflation Factor (VIF). Nilai cutoff yang umum dipakai untuk menunjukkan multikolonieritas adalah nilai Tolerance $\leq 0,10$ atau sama dengan nilai VIF $\geq 10$ (Ghozali, 2012). Berdasarkan hasil uji multikolonieritas yang telah dilakukan, tidak terdapat variabel independen yang memiliki nilai Tolerance kurang dari 0,10 dan nilai VIF lebih dari 10, sehingga dapat disimpulkan bahwa tidak terdapat multikolonieritas antar variabel independen.

Tabel 4.3 Hasil Uji Multikolonieritas

\subsection{Uji Autokorelasi}

Uji autokorelasi

apakah dalam model

antara kesalahan

$\mathrm{t}$ dengan kesalahan

t-1 (sebelumnya). Model
Coefficients $^{\mathrm{a}}$

\begin{tabular}{|ll|r|c|}
\hline \multicolumn{2}{|l|}{ Model } & \multicolumn{2}{|c|}{ Collinearity } \\
& & \multicolumn{2}{|c|}{ Statistics } \\
\cline { 2 - 4 } & & Tolerance & \multicolumn{1}{c|}{ VIF } \\
\hline \multirow{4}{*}{1} & DER & .947 & 1.056 \\
& CR & .756 & 1.323 \\
& ROA & .719 & 1.391 \\
& TAT & .838 & 1.194 \\
& CFO & .928 & 1.077 \\
\hline
\end{tabular}

a. Dependent Variable: Return Saham bertujuan untuk menguji regresi linear ada korelasi pengganggu pada periode pengganggu pada periode regresi yang baik adalah 
regresi yang bebas dari autokorelasi (Ghozali, 2012).Cara untuk mendeteksi terjadinya autokorelasi dalam penelitian ini adalah dengan mengunakan Runs Test.

Berdasarkan hasil uji autokorelasi yang ditunjukkan pada Tabel 4.5, terlihat nilai signifikansi dari hasil Runs Test sebesar 0.272. Melalui hasil pengujian ini, nilai signifikansi lebih besar dari 0.05, yang menunjukkan bahwa tidak terjadi autokorelasi pada model regresi.

Tabel 4.4 Hasil Uji Autokorelasi

\begin{tabular}{|l|r|}
\hline \multicolumn{2}{|c}{ Runs Test } \\
\hline \multicolumn{1}{|c|}{$\begin{array}{c}\text { Unstandardiz } \\
\text { ed Residual }\end{array}$} \\
\hline Test Value $^{\mathrm{a}}$ & -.14857 \\
Cases < Test Value & 27 \\
Cases >= Test & 27 \\
Value & 54 \\
Total Cases & 24 \\
Number of Runs & -1.099 \\
Z & .272 \\
Asymp. Sig. (2- \\
tailed)
\end{tabular}

a. Median

\subsection{Uji Heteroskedastisitas}

Uji heteroskedastisitas bertujuan menguji apakah di dalam model regresi terjadi ketidaksamaan variance dari residual satu pengamatan ke pengamatan yang lain (Ghozali, 2012). Jika variance dari residual satu pengamatan ke pengamatan yang lain tetap, maka disebut Homoskedastisitas dan jika berbeda disebut Heteroskedastisitas. Model regresi yang baik adalah yang Homoskedastisitas atau tidak terjadi Heteroskedastisitas. Cara untuk mendeteksi adanya heteroskedastisitas dalam penelitian ini adalah dengan melihat grafik plot antara nilai prediksi variabel terikat (dependen), yaitu ZPRED dengan residualnya SRESID (Ghozali, 2012).

Dari grafik scatterplot hasil uji heteroskedastisitas didapati bahwa titik-titik menyebar secara acak serta tersebar baik di atas maupun di bawah angka 0 pada sumbu Y, dan tidak membentuk pola tertentu secara teratur (bergelombang, melebar kemudian menyempit). Maka dari itu dapat disimpulkan bahwa tidak terjadi heteroskedastisitas pada model regresi. 
Gambar 4.1 Hasil Uji Heteroskedastisitas

Scatterplot

Dependent Variable: Return Saham

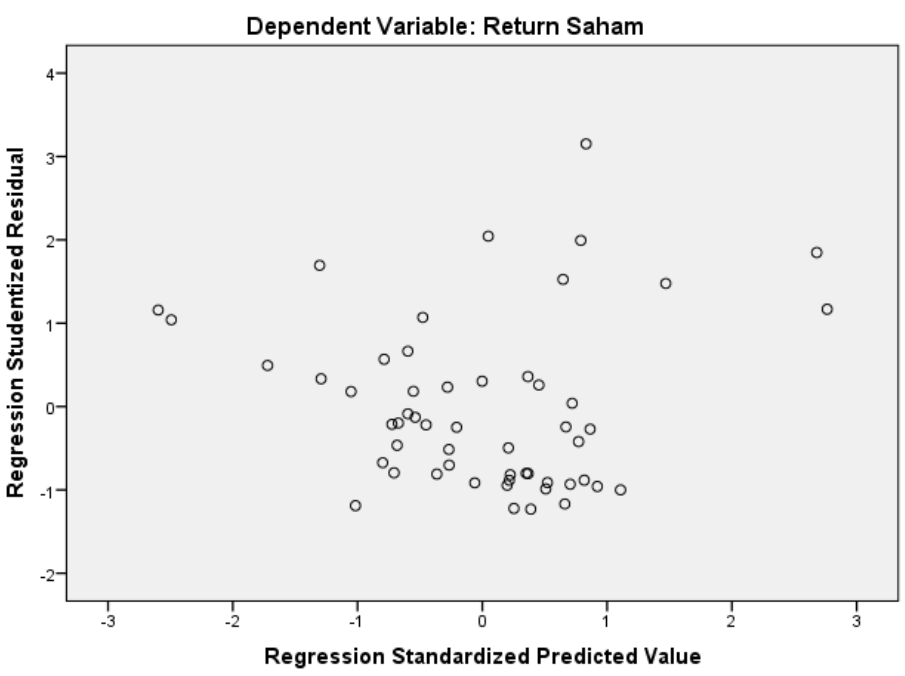

\subsection{Uji Hipotesis}

Berdasarkan uji asumsi klasik yang telah dilakukan pada model regresi tersebut, maka model regresi tidak memiliki asumsi multikolonieritas, heteroskedastisitas, autokorelasi negatif maupun positif, serta data telah terdistribusi normal. Uji hipotesis dilakukan untuk mengetahui pengaruh $D E R, C R, R O A, T A T$, dan $C F O$ secara parsial maupun simultan terhadap return saham.

Tabel 4.5 Hasil Uji Koefisien Determinasi

Model Summary ${ }^{\text {b }}$

\begin{tabular}{|l|r|r|r|r|}
\hline $\begin{array}{l}\text { Mode } \\
1\end{array}$ & R & R Square & $\begin{array}{c}\text { Adjusted R } \\
\text { Square }\end{array}$ & $\begin{array}{r}\text { Std. Error of } \\
\text { the Estimate }\end{array}$ \\
\hline 1 & $.598^{\mathrm{a}}$ & .357 & .290 & .7086661 \\
\hline
\end{tabular}

a. Predictors: (Constant), CFO, CR, DER, TAT, ROA

b. Dependent Variable: Return Saham 
ANOVA ${ }^{\mathrm{a}}$

\begin{tabular}{|c|c|c|c|c|c|c|}
\hline \multicolumn{2}{|c|}{ Model } & $\begin{array}{l}\text { Sum of } \\
\text { Squares }\end{array}$ & $\mathrm{df}$ & $\begin{array}{c}\text { Mean } \\
\text { Square }\end{array}$ & $\mathrm{F}$ & Sig. \\
\hline \multirow{3}{*}{1} & Regression & 13.403 & 5 & 2.681 & 5.338 & $.001^{b}$ \\
\hline & Residual & 24.106 & 48 & .502 & & \\
\hline & Total & 37.509 & 53 & & & \\
\hline
\end{tabular}

a. Dependent Variable: Return Saham

b. Predictors: (Constant), CFO, CR, DER, TAT, ROA

Tabel 4.7 Hasil Uji Statistik t

Coefficients $^{\mathrm{a}}$

\begin{tabular}{|c|c|c|c|c|c|c|}
\hline \multirow{2}{*}{\multicolumn{2}{|c|}{ Model }} & \multicolumn{2}{|c|}{$\begin{array}{c}\text { Unstandardized } \\
\text { Coefficients }\end{array}$} & \multirow{2}{*}{$\begin{array}{c}\text { Standardized } \\
\text { Coefficients } \\
\text { Beta }\end{array}$} & \multirow[t]{2}{*}{$\mathrm{t}$} & \multirow[t]{2}{*}{ Sig. } \\
\hline & & B & Std. Error & & & \\
\hline \multirow{6}{*}{1} & (Constant & -.190 & .395 & & -.479 & .634 \\
\hline & DER & .446 & .096 & .550 & 4.627 & .000 \\
\hline & $\mathrm{CR}$ & -.028 & .178 & -.021 & -.155 & .877 \\
\hline & $\mathrm{ROA}$ & 4.245 & 1.962 & .295 & 2.164 & .035 \\
\hline & TAT & .045 & .170 & .034 & .266 & .791 \\
\hline & $\mathrm{CFO}$ & -.002 & .002 & -.140 & -1.164 & .250 \\
\hline
\end{tabular}

a. Dependent Variable: Return Saham

Hasil analisis regresi berganda secara keseluruhan menunjukkan angka Adjusted $R^{2}$ sebesar 29\% dengan tingkat signifikansi sebesar 0,001 (pvalue < 0,05). Hal ini menjelaskan bahwa terdapat pengaruh yang signifikan antara variabel-variabel independen secara simultan terhadap variabel dependennya, sehingga dapat disimpulkan bahwa $\mathrm{Ha}_{6}$ diterima. Variasi variabel dependen dalam penelitian ini yaitu return saham hanya bisa dijelaskan oleh variabel independennya sebesar $29 \%$.

Uji statistik t untuk variabel $D E R$ sebesar 4.627 dengan tingkat signifikansi 0.000 yang lebih kecil dari 0.05 , sehingga dapat disimpulkan bahwa $\mathrm{Ha}_{1}$ diterima. Hal ini menunjukkan bahwa Debt to Equity Ratio (DER) memiliki pengaruh signifikan terhadap return saham.

Hasil uji statistik t untuk variabel $C R$ sebesar -0.155 dengan tingkat signifikansi 0.877 yang lebih besar dari 0.05 , sehingga dapat disimpulkan bahwa $\mathrm{Ha}_{2}$ ditolak. Hal ini berarti Current Ratio (CR) tidak memiliki pengaruh terhadap return saham. Tinggi atau rendahnya current ratio tidak mempengaruhi keputusan investor dalam melakukan investasi. Terlihat dari meningkatnya rata-rata harga saham perusahaan walaupun terjadi fluktuasi nilai current ratio sepanjang tahun 2010-2012. Hal ini dapat disebabkan karena investor tidak melihat 
current ratio dalam memutuskan untuk melakukan investasi melainkan melihat peningkatan harga saham untuk keuntungan jangka pendek.

Hasil uji statistik t untuk ROA sebesar 2.164 dengan tingkat signifikansi 0.035 yang lebih kecil dari 0.05 , sehingga dapat disimpulkan bahwa $\mathrm{Ha}_{3}$ diterima. Hal ini menunjukkan bahwa Return On Asset (ROA) memiliki pengaruh signifikan terhadap return saham.

Hasil uji statistik t untuk TAT sebesar 0.266 dengan tingkat signifikansi 0.791 yang lebih besar dari 0.05 , sehingga dapat disimpulkan bahwa $\mathrm{Ha}_{4}$ ditolak. Hal ini berarti Total Asset Turnover (TAT) tidak memiliki pengaruh terhadap return saham. Hal ini dapat dilihat dari perubahan harga saham yang tidak sejalan dengan perubahan total asset turnover perusahaan. Walaupun rasio total asset turnover perusahaan berfluktuasi, rata-rata harga saham perusahaan sepanjang tahun 2010-2012 tetap meningkat.

Hasil uji statistik t untuk $C F O$ sebesar -1.164 dengan tingkat signifikansi 0.250 yang lebih besar dari 0.05, sehingga dapat disimpulkan bahwa $\mathrm{Ha}_{5}$ ditolak. Hal ini menunjukkan bahwa Cash Flow from Operating (CFO) tidak memiliki pengaruh terhadap return saham. Hal inidapat disebabkan karena investor tidak melihat rasio cash flow from operating sebagai pertimbangan dalam melakukan investasi. Terlihat dari meningkatnya rata-rata harga saham perusahaan sepanjang tahun 2010-2012 walaupun terjadi penurunan dan peningkatan dalam rasio cash flow from operating.

Berdasarkan hasil uji statistik $\mathrm{t}$, diperoleh hasil persamaan regresi yang digunakan dalam penelitian ini, yaitu:

Return Saham $=-0.190+0.446$ DER $-0.028 C R+4.245 R O A+0.045 T A T-0.002 C F O$

Nilai koefisien regresi untuk variabel Debt to Equity Ratio (DER) adalah sebesar 0.446 yang berarti bahwa setiap kenaikan $1 \%$ DER akan menyebabkan peningkatan return saham sebesar $44.6 \%$.

Variabel Current Ratio $(C R)$ memiliki nilai koefisien regresi sebesar -0.028 yang berarti bahwa setiap kenaikan $1 \% C R$ akan menyebabkan penurunan return saham sebesar 2.8\%. Hal ini dapat disebabkan karena proporsi aset lancar perusahaan untuk kas lebih sedikit dibandingkan persediaan perusahaan sehingga memungkinkan perusahaan untuk tidak membagikan dividen. Apabila perusahaan tidak memungkinkan untuk membagikan dividen, maka investor tidak tertarik untuk melakukan investasi pada perusahaan tersebut sehingga permintaan atas saham perusahaan akan menurun dan diiringi dengan penurunan harga saham dan return saham.

Variabel Return On Asset (ROA) adalah sebesar 4.245 yang berarti bahwa setiap kenaikan 1\% ROA akan menyebabkan peningkatan return saham sebesar $424.5 \%$.

Variabel Total Asset Turnover (TAT) adalah sebesar 0.045 yang berarti bahwa setiap kenaikan 1\% TAT akan menyebabkan peningkatan return saham sebesar $4.5 \%$.

Variabel Cash Flow from Operating (CFO) adalah sebesar -0.002 yang berarti bahwa setiap kenaikan $1 \%$ CFO akan menyebabkan penurunan return saham sebesar $0.2 \%$. Hal ini dapat disebabkan karena arus kas operasi dan laba akuntansi dapat memberikan informasi yang bertentangan, yaitu kenaikan laba dapat diikuti oleh penurunan arus kas. Meningkatnya arus kas operasi perusahaan tidak menjamin kemampuan perusahaan untuk membagikan dividen. Perusahaan yang mampu membayar dividen kepada pemegang saham merupakan perusahaan yang memiliki laba dan sekaligus dana tunai yang cukup. Apabila perusahaan tidak memungkinkan untuk membagikan dividen, maka minat investor untuk melakukan investasi juga berkurang sehingga permintaan atas saham perusahaan menurun dan diiringi dengan penurunan harga saham dan return saham. 


\section{Simpulan, Keterbatasan, dan Saran}

\subsection{Simpulan}

Penelitian ini menguji pengaruh debt to equity ratio, current ratio, return on asset, total asset turnover, dan cash flow from operating, baik secara simultan maupun individual terhadap return saham. Simpulan yang diperoleh dari hasil penelitian ini adalah:

1. Debt to Equity Ratio (DER) berpengaruh secara signifikan terhadap return saham.

2. Current Ratio $(C R)$ tidak berpengaruh terhadap return saham.

3. Return On Asset (ROA) berpengaruh secara signifikan terhadap return saham.

4. Total Asset Turnover (TAT)tidak berpengaruh terhadap return saham.

\subsection{Implikasi Hasil Penelitian}

Penelitian ini dapat membantu investor dalam melakukan analisa investasi, dimana investor yang mengharapkan return saham yang tinggi dapat menganalisa dengan melihat dari debt to equity ratio dan return on asset. Dimana dalam penelitian ini didapatkan hasil bahwa debt to equity ratio dan return on asset memiliki pengaruh signifikan terhadap return saham.

\subsection{Keterbatasan}

Keterbatasan dari penelitian yang dilakukan adalah sebagai berikut:

1. Sampel penelitian yang diambil adalah perusahaan manufaktur yang tergolong dalam sektor aneka industri yang terdaftar di BEI, sehingga hasil penelitian ini tidak dapat digeneralisasi untuk semua perusahaan manufaktur.

2. Variabel independen yang digunakan dalam penelitian ini dapat menjelaskan variabel dependen sebesar $29 \%$ dan sisanya $71 \%$ dijelaskan oleh variabel lain yang tidak diteliti dalam penelitian ini.

\subsection{Saran}

Berdasarkan simpulan dan keterbatasan dalam penelitian ini, maka saran yang diajukan untuk penelitian selanjutnya adalah:

1. Memperluas sampel penelitian seperti sektor industri dasar dan kimia dan sektor industri barang konsumsi agar dapat digeneralisasi untuk semua perusahaan manufaktur

2. Menambahkan variabel-variabel independen seperti tingkat inflasi atau ukuran perusahaan.

\section{REFERENSI}

Agoes, Sukrisno. 2012. Auditing: Petunjuk Praktis Pemeriksaan Akuntan oleh Akuntan Publik. Jakarta: Salemba Empat.

Arens, Alvin A., dkk. 2012. Auditing and Assurance Services: An Integrated Approach, 14th 
Edition. Singapore: Pearson.

Bursa Efek Indonesia (BEI). 2011. Indonesian Capital Market Directory (ICMD) 2011. Jakarta: ECFIN.

Dewayanto, Totok. 2011. "Analisis Faktor-Faktor yang Mempengaruhi Penerimaan Opini Audit Going Concern pada Perusahaan Manufaktur yang Terdaftar di Bursa Efek Indonesia". Jurnal Jurnal Stie Semarang Vol. 3 No. 2.

Diyanti, Fitri Tri. 2010. "Pengaruh Debt Default, Pergantian Auditor, dan Ukuran Perusahaan terhadap Penerimaan Opini Audit Going Concern". Jurnal Universitas Gunadarma.

Ghozali, Imam. 2011. Aplikasi Analisis Multivariate dengan Program SPSS. Semarang: Badan Penerbit Universitas Diponegoro.

Gitman, Lawrence J.2009. Principles of Managerial Finance. UK: Pearson/Addison Wesley.

Herusetya, Antonious. 2008. "Kaitan Firm Size KAP terhadap Mutu Laporan Audit Going Concern: Studi di Indonesia”. Jurnal Akuntansi dan Keuangan Indonesia Vol.2 No.1.

Ikatan Akuntan Indonesia (IAI). 2012. "Pernyataan Standar Akuntansi Keuangan No. 1 (Revisi 2009)". Dalam www.iaiglobal.or.id.

Indriyani, Rosmawati Endang dan Supriyati. 2012. "Faktor-Faktor yang Mempengaruhi Audit Report Perusahaan Manufaktur di Indonesia dan Malaysia". The Indonesian Accounting Review Vol.2 No. 2.

Institut Akuntan Publik Indonesia (IAPI). 2011. Standar Profesional Akuntan Publik. Jakarta: Salemba Empat.

Januarti, Indira dan Ella Fitrianasari.2008. “Analisis Rasio Keuangan dan Rasio NonKeuangan yang Mempengaruhi Auditor dalam Memberikan Opini AuditGoing Concern pada Auditee". Jurnal Manajemen, Akuntansi dan SistemInformasi UniversitaDiponegoro Vol. 8 No.1.

Kartika, Andi. 2009. "Faktor-Faktor yang Mempengaruhi Audit Delay di Indonesia (Studi Empiris pada Perusahaan-Perusahaan LQ45 yang Terdaftar di Bursa Efek Jakarta)". Jurnal Bisnis dan Ekonomi Vol. 16 No.1.

Lianto, Novice dan Budi Hartono Kusuma. 2010. "Faktor-Faktor yang Berpengaruh terhadap Audit Report Lag". Jurnal Bisnis dan Akuntansi Vol.12

No.2.

Meriani, Ni Putu dan Komang Ayu Krisnadewi. 2012. "Pengaruh Kondisi Keuangan, Pertumbuhan Perusahaan, dan Reputasi Auditor pada Pengungkapan Opini Audit Going Concern". Electronic Journal Universitas Udayana Vol.7 No.1.

Parwati, Lina Anggraeny dan Yohanes Suhardjo. 2009. "Faktor-Faktor yang Mempengaruhi Audit Report Lag". Jurnal Solusi Vol. 8 No.3. 
Praptitorini, Mirna Dyah dan Indira Januarti. 2007. "Analisis Pengaruh Kualitas Audit, Debt Default dan Opinion Shopping terhadap Penerimaan Opini Going Concern". Simposium Nasional Akuntansi X Makasar.

Putra, I Gede Cahyadi. 2012. "Opini Audit Going concern: Prediksi Kebangkrutan dan Auditor Independen". Jurnal Riset Akuntansi (Juara) Universitas Mahasaraswati Denpasar.

Rahman, Abdul dan Baldric Siregar. 2012. "Faktor-Faktor yang Mempengaruhi Kecenderungan Penerimaan Opini Audit Going Concern pada Perusahaan Manufaktur yang Terdaftar di Bursa Efek Indonesia". Simposium Nasional Akuntansi XV Banjarmasin.

Ramadhani, Ayu Suci dan Niki Lukviarman. 2009. "Perbandingan Analisis Prediksi Kebangkrutan Menggunakan Model Altman Pertama, Altman Revisi, dan Altman Modifikasi dengan Ukuran dan Umur Perusahaan sebagai Variabel Penjelas (Studi pada Perusahaan Manufaktur yang Terdaftar di Bursa Efek Indonesia)". Jurnal Siasat Bisnis Vol. 13 No. 1.

Rudyawan, Arry Pratama dan I Dewa Nyoman Badera. 2009. "Opini Audit Going Concern: Kajian Berdasarkan Model Prediksi Kebangkrutan, Pertumbuhan Perusahaan, Leverage, dan Reputasi Auditor”. Electronic Journal Universitas Udayana Vol.4 No.2.

Santosa, Arga Fajar dan Linda Kususmaning Wedari. 2007. "Analisis Faktor-Faktor yang Mempengaruhi Kecenderungan Penerimaan Opini Audit Going

Concern". Jurnal Akuntasi dan Audit Indonesia Vol. 11 No. 2.

Sari, Anna Indrakila dan Wahyu Meiranto. 2012. “Pengaruh Kualitas Audit, Opini Audit sebelumnya, Ukuran Perusahaan, dan Kepemilikan PerusahaanTerhadap Penerimaan Opini Audit Going Concern (Studi Empiris Perusahaan Manufaktur yang Terdaftar di Bursa Efek Indonesia). Jurnal Universitas Diponegoro.

Sekaran, Uma and Roger Bougie. 2010. Research Methods For Business : A Skill Building Approach. USA: John Willey \& Sons, Inc.

Susanto, Yulius Kurnia. 2009. "Faktor- Faktor yang Mempengaruhi Penerimaan Opini Audit Going Concern pada Perusahaan Publik Sektor Manufaktur".

Jurnal Bisnis dan Akuntansi Vol. 11 No.3.

Susarni, Ovi dan Singgih Jatmiko. 2012. "Analisis Faktor-Faktor yang Mempengaruhi Penerimaan Opini Audit Going Concern”. Jurnal Universitas Gunadarma.

Ulya, Alfaizatul. 2012. "Opini Audit Going Concern: Analisis Berdasarkan Faktor Keuangan dan Non-Keuangan”. Accounting Analysis Journal Vol. 1 No. 1.

Universitas Multimedia Nusantara. 2012. Panduan Skripsi Fakultas Ekonomi, Program Studi Akuntansi, Universitas Multimedia Nusantara. Tangerang. 
Warnida. 2011. "Analisis Faktor-Faktor yang Mempengaruhi Penerimaan Opini Audit Going Concern". Jurnal Akuntansi dan Manajemen Vol. 6 No. 1.

Widyantari, A.A.Ayu Putri.2010. "Opini Audit Going Concern dan Faktor-Faktor yang Memengaruhi: Studi pada Perusahaan Manufaktur di Bursa Efek Indonesia". Jurnal Universitas Udayana.

www.sahamok.com

www.finance.yahoo.com

www.idx.co.id

www.math.unb.ca 